\title{
UV DAMAGE TO THE EYE LENS: Further Results from Animal Model Studies: A review
}

\author{
Otto Hockwin 1, 2, Masami Kojima ', Yasuo Sakamoto ${ }^{1}$, Alfred Wegener ${ }^{2}$, Ying Bo Shui ${ }^{1}$, \\ and Kazuyuki Sasaki 1
}

\begin{abstract}
UV irradiation has the potential to induce the development of lens opacities. This has been demonstrated since long with animal experiments. Unfortunately these animal cataracts did not explain or elucidate the epidemiological observation that the frequency of human cataracts such as the so called senile cataract - is remarkably higher in regions with increased cosmic UV irradiation or in the population being in close professional contact with UV-irradiation. The main problem was that the type of UV induced animal cataracts differs remarkably with respect to onset, localization of the opacity, size and its timely progression from the cataract classes observed in human. The research of the last 10 years comes to the conclusion that beside the direct (acute) damage - as seen in animal studies due to high UV dosages- we have to realize a syn- or co-cataractogenic potential of UV irradiation even below the threshold dose which is able to accumulate in the lens and to initiate together with other risk factors (chronic damage) the opacification of the lens. The mechanism for the animal cataract and the human cataract (with an UV risk participation) are different. The epidemiological research about cataract frequency in different regions of the world have to take into account that UV irradiation -even below a threshold dose - is a possible risk among the multifactorial pathogenesis of human cataract.

J Epidemiol, $1999 ; 9$ : S39-S47.
\end{abstract}

UV irradiation; eye lens; human cataracts; experimental cataracts; acute and chronic lens damage, syn- and cocataractogenesis; UV irradiation and senile cataracts

Exactly 5 years ago during the TSUKUBA Ozone Workshop in 1994 I was able to outline a review of the UV-B induced eye injuries, especially of the eye lens ${ }^{1)}$. Research in this field has been worldwide activated and progressed further and I want to present today the latest results of a subject which has become of high interest to Ophthalmologists, Epidemiologists, Basic Researchers such as Biochemists and last but not least to Public Health Organisations.

5 years ago the observation of an increased frequency of human cataracts in regions with higher cosmic UV radiation was still without any significant and firm proof, that the UV radiation is really responsible for this epidemiological outcome. There was a broad trench between the epidemiological findings and the experimental approaches, the main difference was the type of cataracts within the usual classification and the remarkable differences in the latency periods between radiation and onset of lens changes. Nothing similar was observed in human what was seen in animal studies with UV radiation. At this time there was no acceptable explanation others than a species difference between human lenses and the experimental animal lenses (mice, rats, rabbits). The main error then was the assumption that we have to realize only one damaging mechanism for the lens by UV radiation. The research findings of the last 5 years are best explained by an approach which is used generally in elucidations of pathological findings as an issue of extracorporal hazards or risks.

Risk assessment of human diseases requires

1) assessment of exposure

2) assessment of hazard identification

3) dose-response dependency

4) risk characterisation among multifactorial processes

${ }^{1}$ Department of Ophthalmology, Kanazawa Medical University, Uchinada, Ishikawa, 920-02 Japan.

${ }^{2}$ Medizinische Fakultät, Rheinische Friedrich-Wilhelms-Universität Bonn, Germany.

Address for correspondence : Prof. Dr. Otto Hockwin Zentrum für Augenheilkunde der Univ. Bonn Tulpenweg 4 D-53757 Sankt Augustin Deutschland. 


\section{ASSESSMENT OF EXPOSURE}

It has become undisputable that UV radiation has the potential to induce the development of lens opacities. A large number of animal studies (see extensive literature references in ${ }^{2,3}$ ) and clinical investigations ${ }^{4,5,6)}$ have created considerable evidence for this. In addition, epidemiological studies for cataract incidence in different regions of the world ${ }^{7}$ provided strong arguments for the involvement of UV radiation in cataract development.

\section{HAZARD IDENTIFICATION}

The direct damage to the eye lens by UV B irradiation of a sufficient dosage can be observed with slit lamp microscope and best demonstrated with slit images according to SCHEIMPFLUG principle. The damage first is seen in the center of the anterior lens surface as a whitish spot directly underneath the lens capsule (Figure 1).

A histological preparation (Figure 2) demonstrates the location of the early damage within the lens epithelium. From there we observe a penetration of the damage into the deeper lens layers with formation of plaques and water filled areas. The lens structure is deteriorated and the opacified area becomes larger, the cataract formation is progressing.

We want to stress that this type of UV B radiation damage of the lens is characteristic only for the direct effect (damage in relatively close time connection to the irradiation by high dosages). In general we do not observe this type of opacity in human beings, only very occasional by accidents (Figure 3 ) with unshielded (or defect safety constructions) UV sources in professional applications as mentioned already in the assessment of exposure ${ }^{46}$ ). Missing this type of cataract among the observed cataracts of epidemiological studies makes it difficult, to accept the frequently manifested opinion that UV radi- ation contributes to the higher frequency of cataracts in regions with elevated cosmic UV irradiation or in the population with higher UV radiation as professional hazard (bath attendants, fishermen, gardeners, farmers, sailors, roadmen, masons, workers in certain projects in chemical and pharmaceutical industry, lithography, copy machine operators, welders etc.) Harding ${ }^{8)}$ completely denies a relationship of cataractogenesis and sunlight, he refers to other well-known risks.

In the meantime there is ample evidence that the epidemiological observations about a participation of UV irradiation in the formation of cataracts are correct ${ }^{7,9}$, but this is very different from what we have shown as direct damage of the lens by UV irradiation. Here we have to realize the fact that human cataracts (Figure 4), mostly the so called senile cataracts, are a consequence of a multifactorial pathogenesis ${ }^{10,11}$. I will come back to this problem under the aspect of assessment of UV damage and its risk characterisation among multifactorial processes.

\section{DOSE RESPONSE DEPENDENCY}

The first signs of a transparency loss in the lens are correlated to the dosage, a higher dosage leads to a shorter latency period between radiation application and appearance of visible opacities.The age of the animals at time of radiation also is of important influence, the younger the animals the shorter the latency period.

A general threshold dosage for UV radiation could not be determined yet, although several threshold levels have been proposed in animal studies ${ }^{12,13)}$.

However these results cannot be taken as valid for cataract triggering in human. One of the main underlying problems in this context is the determination of the exact dosage, which really hits the lens ${ }^{14}$, not the ambient dosage in this case, is of importance which most probably differs considerably. Several
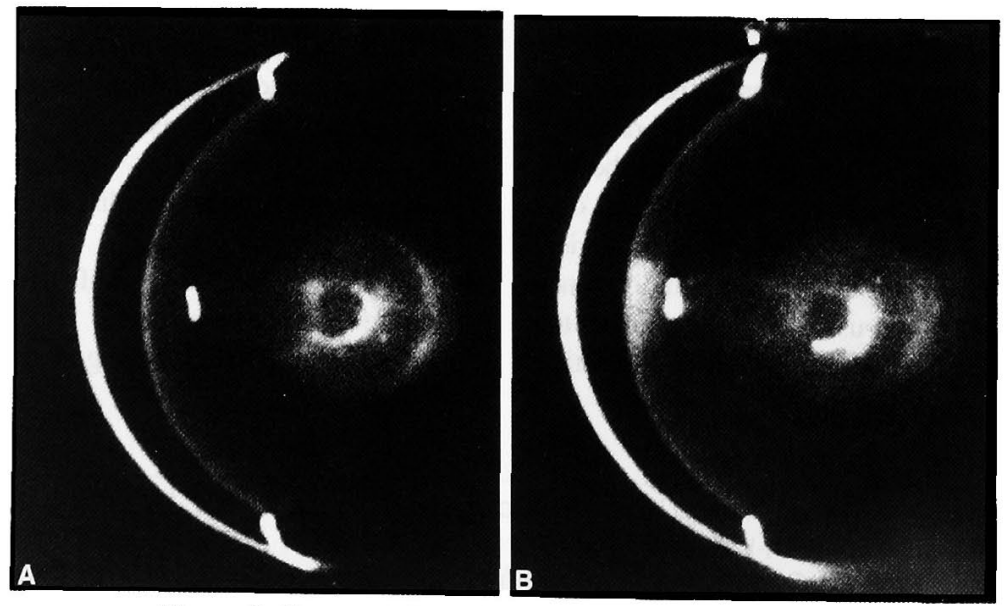

Figure 1. Cataract induced by UV-B irradiation, rat lens ${ }^{19}$. 

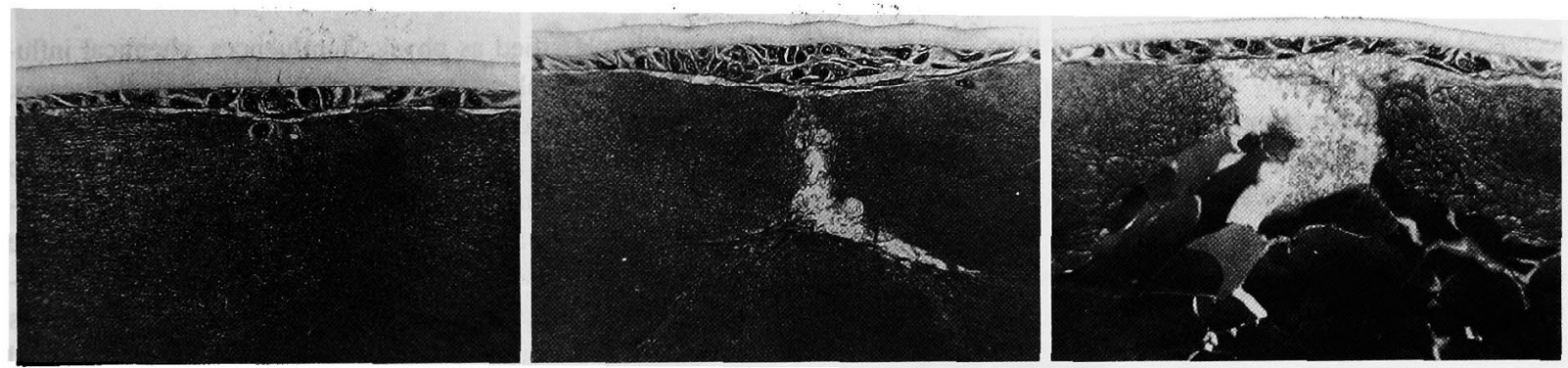

Figure 2. Histological examinations of rat lenses at different times after UV-B irradiation ${ }^{2,28)}$.
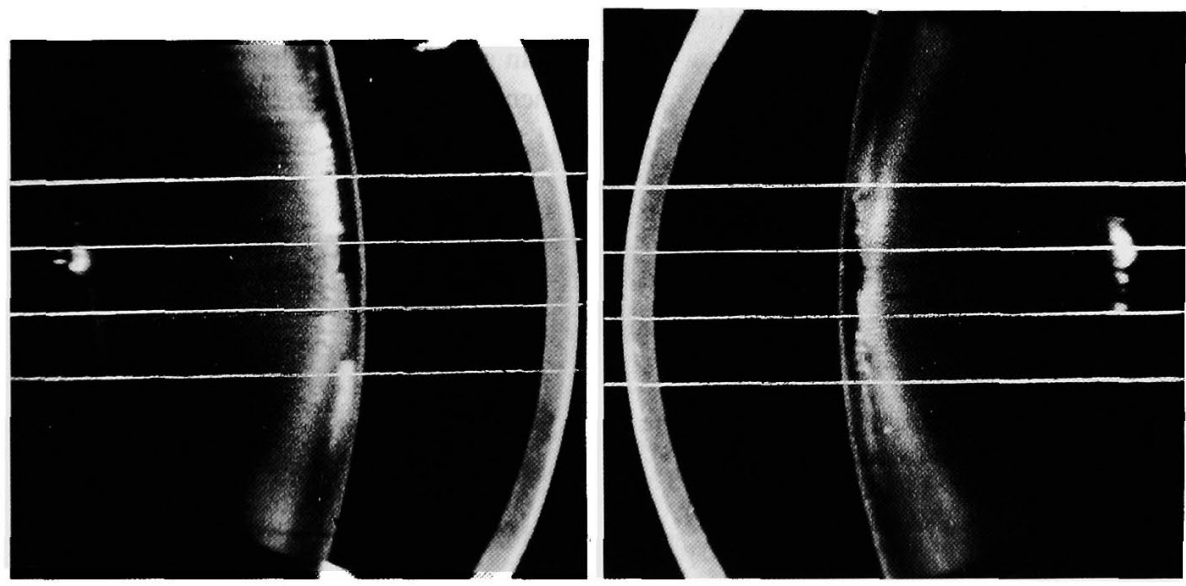

Figure 3. Cataract induced by UV irradiation in human eyes, occupational disease after exposure for many years; cause-effect relationship was confirmed by dose measurements under realistic exposure conditions ${ }^{5,6)}$.

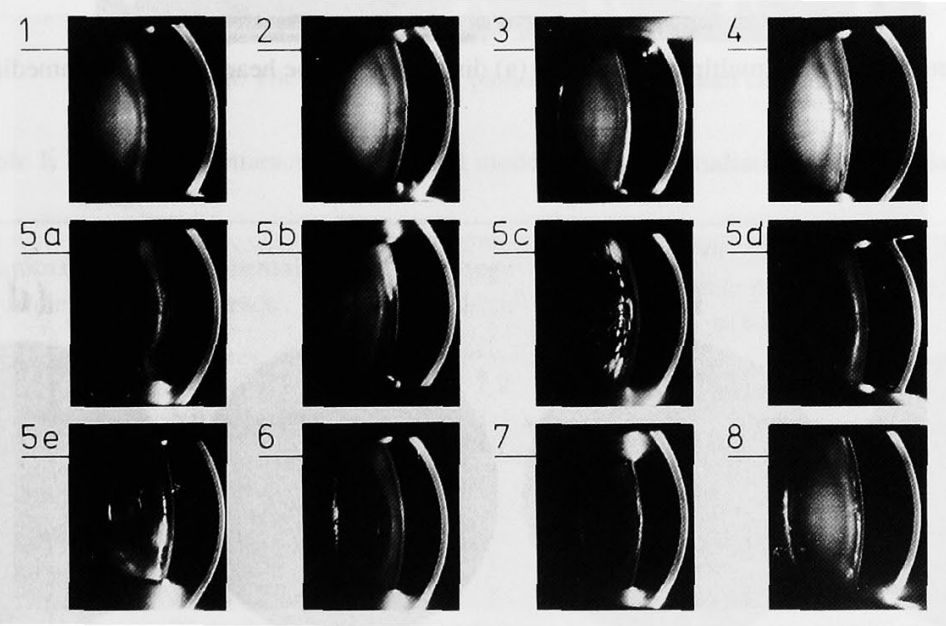

Figure 4. During a screening examination in several ophthalmologists offices in the area of Bonn/Germany we were able to differentiate 8 main cataract classes. Class 5 with cortical opacities and almost completely transparent lens nucleus was divided into 5 subgroups of different types of opacities "'). 
technical attempts have been made to determine "lens dosage": Construction of a dummy head with multiple dosimeters ${ }^{15)}$ or UV sensitive contact lenses placed on the cornea of human ${ }^{16}$ ) or rabbit ${ }^{17}$ eyes (Figures 5, 6, 7).

In addition in-vivo as well as in-vitro investigations on organ and cell levels in culture systems provide further insight into characteristics and underlying mechanisms of UV damage to the eye lens ${ }^{18,19,20,21)}$.

\section{RISK CHARACTERISATION AMONG MULTIFACTORIAL PROCESSES}

The pathogenesis of cataracts in humans - mainly of the so-called Senile Cataract proved to be a multifactorial process ${ }^{10,11)}$. A number of risk factors involved have been clearly identified, other are still under investigation, they may be roughly classified as physical influences, chemical influences. geographical influences, eye diseases, general diseases, nutritional deficiencies/disturbances, life style etc. (Figure 8).

In accepting UV radiation as a risk factor for the lens it has to be taken into account that it can not only damage the lens properties directly with a development of UV-induced opacities, we also have to assume that UV radiation is able to enhance (cocataractogenesis) an ongoing opacifying process in the lens (even the UV radiation dosage does not reach the "threshold level") thus promoting the formation of cataracts ${ }^{22,23)}$.

This is supported by the observation that in clinical studies we do not find the same type of cataract which is typical for UV damage in animals (as discussed earlier), what we do find is an increased frequency of the so-called "senile cataracts" 11).

In consequence during the past decade a number of experimental studies tried to elucidate the co-cataractogenic potential
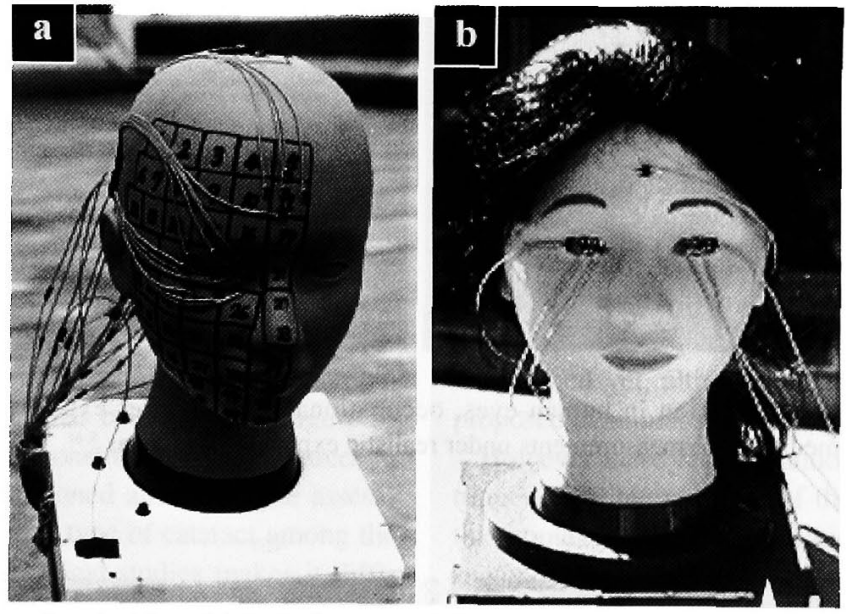

Figure 5. Construction of a dummy head with multiple dosimeters (a) distributed on the head and in the immediate neighbourhood of the eye ${ }^{15}$.

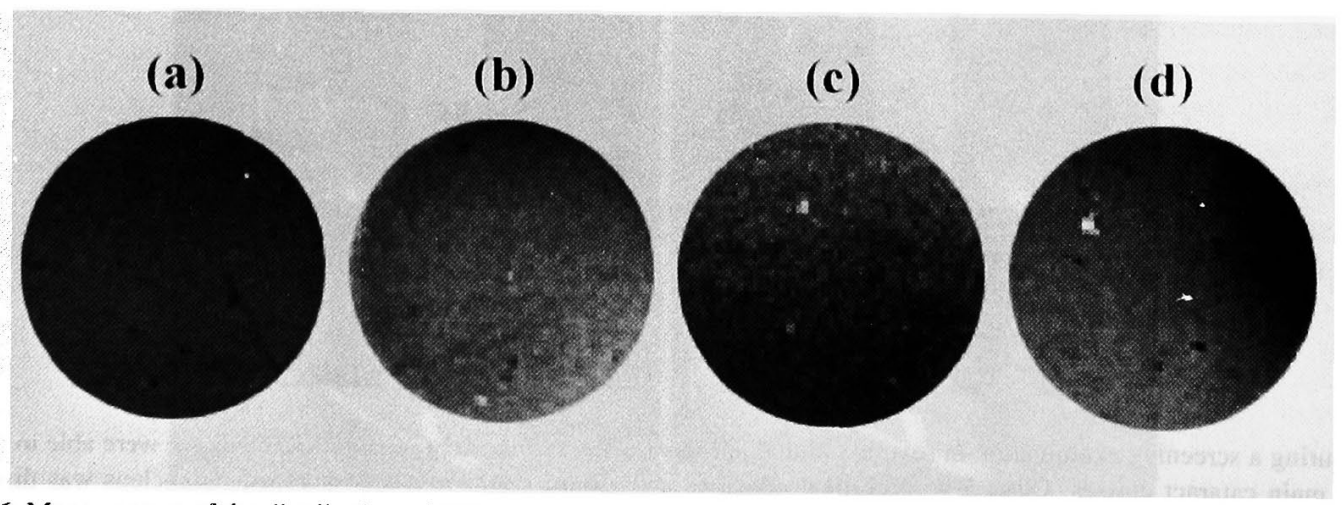

Figure 6. Measurement of the distribution of UV-B irradiation in the corneal surface of rabbit eyes ${ }^{34}$ using special contact lenses. 


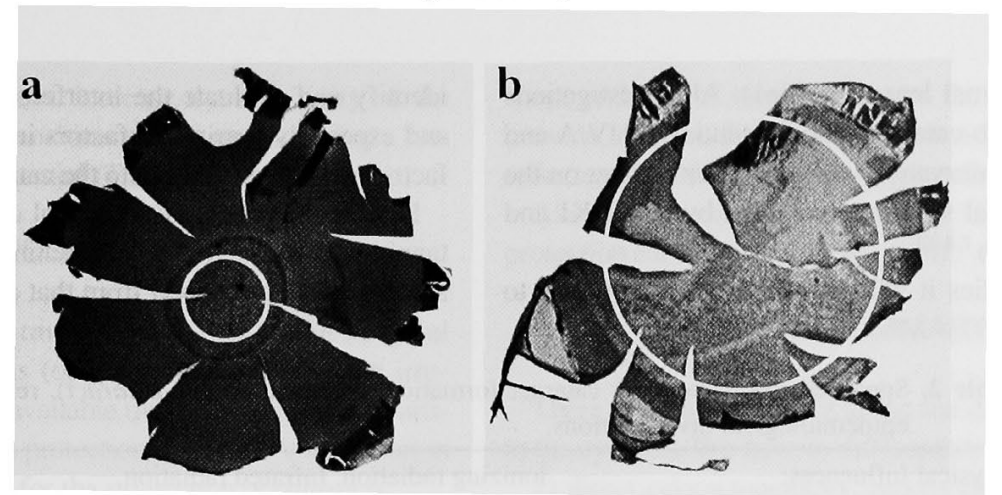

Figure 7. Effect of pupillary dilation in rabbit eyes on the area of injured lens epithelial cells by UV-B irradiation ${ }^{34}$.

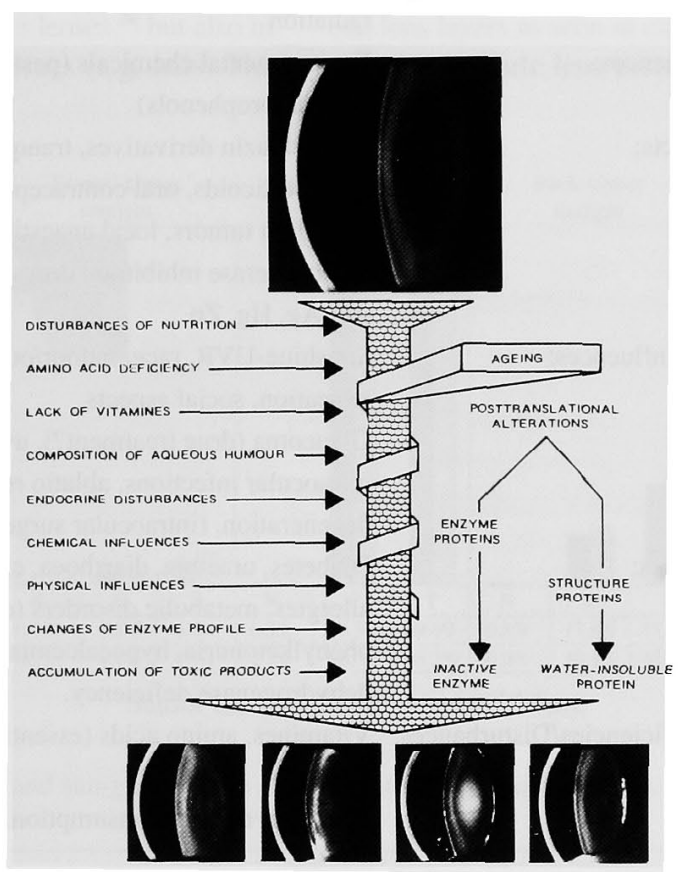

Figure 8. The multifactorial pathogenesis of human cataracts '"'.

Table 1. Syn-and Co-cataractogenic animal models with UV-irradiation as a potential risk factor.

\begin{tabular}{|c|c|c|c|c|c|c|}
\hline \multirow{2}{*}{$\begin{array}{l}\text { animal } \\
\text { species }\end{array}$} & \multirow{2}{*}{$\begin{array}{l}\text { experimental } \\
\text { Cataract }\end{array}$} & \multicolumn{2}{|c|}{ UV-dosage } & \multirow{2}{*}{\multicolumn{2}{|c|}{$\begin{array}{c}\text { Syn- or Co- } \\
\text { Cataractogenic potential } \\
\text { of the UV irradiation }\end{array}$}} & \multirow{2}{*}{ Reference } \\
\hline & & $\mathrm{A} / \mathrm{B}$ & $\mathrm{J} / \mathrm{cm}^{2}$ & & & \\
\hline Mice & Hereditary & (B) & 2,2 & & $\star$ & (24) \\
\hline guinea pig & Vit C def. & (B) & $0.2-1.2$ & & $\star$ & (25) \\
\hline rat & $\begin{array}{l}\text { Buthionine- } \\
\text { Sulfoximine }\end{array}$ & (B) & 0.067 & $\star$ & & (26) \\
\hline rat & Diabetic & (B) & 0.2 & $\star$ & & (27) \\
\hline \multirow[t]{4}{*}{ rat } & Diabetic & (A) & 1 & & $\star$ & $(28,29)$ \\
\hline & $X$-ray & (A) & 1 & & $\star$ & \\
\hline & Diabetic & (B) & 0.2 & $\star$ & & \\
\hline & $\mathrm{X}$-ray & (B) & 0.2 & $\star$ & & \\
\hline rat & $\begin{array}{l}\text { Zinc/Vit E } \\
\text { deficiency }\end{array}$ & (A) & 1 & $\star$ & & (30) \\
\hline
\end{tabular}


of UV radiation in animal lenses (Table1). All investigations confirmed the syn- or co-cataractogenic potential of UV A and UV B irradiation, an observation with important impact on the ongoing epidemiological studies, conducted by SASAKI and his cataract study group ${ }^{7,9,31}$.

In these clinical studies it will be of utmost importance to identify and evaluate the interference of geographical, racial and especially nutritional factors involved. But also other risk factors may have an input to the cataract formation (Table 2).

Further important risk potential comes from using cosmetic tanning devices and from leisure time activities (skying, sailing and many others). Apart from that a number of drugs, some of

Table 2. Specified risk factors for cataract formation in human (senile cataract), results of epidemiological investigations.

\begin{tabular}{ll}
\hline Physical Influences: & $\begin{array}{l}\text { lonizing radiation, Infrared radiation, } \\
\text { Electromagnetic fields, UV-irradiation, RADAR- } \\
\text { radiation }\end{array}$ \\
Chemical Influences: & $\begin{array}{l}\text { } \\
\text { poly-chlorophenols) } \\
\text { Phenothiazin derivatives, tranquilizers, } \\
\text { glucocorticoids, oral contraceptiva, chemotherapy } \\
\text { of malign tumors, local anaestitics, miotics, } \\
\text { cholinesterase inhibitors, drugs containing }\end{array}$ \\
& $\begin{array}{l}\text { Au, Ag, Hg, Zn. } \\
\text { Sunshine-UVR, race, indoor/outdoor occupatuion, } \\
\text { education, social aspects. }\end{array}$ \\
Geographical Influences: & $\begin{array}{l}\text { Glaucoma (drug treatment?), uveitis, retinitis, } \\
\text { Eye Diseases: }\end{array}$ \\
intraocular infections, ablatio retinae, tapeto-retinal- \\
degeneration, (intraocular surgery?) \\
Diabetes, uraemia, diarrhoea, chronic bronchitis, \\
allergies, metabolic disorders (cholesterol/lipids), \\
phenylketonuria, hypocalcemia, G-6-P- \\
dehydrogenase deficiency.
\end{tabular}

Table 3. Drugs with known photosensitizing effects, which may have a risk potential for Cataract development especially taken as long-term therapy.

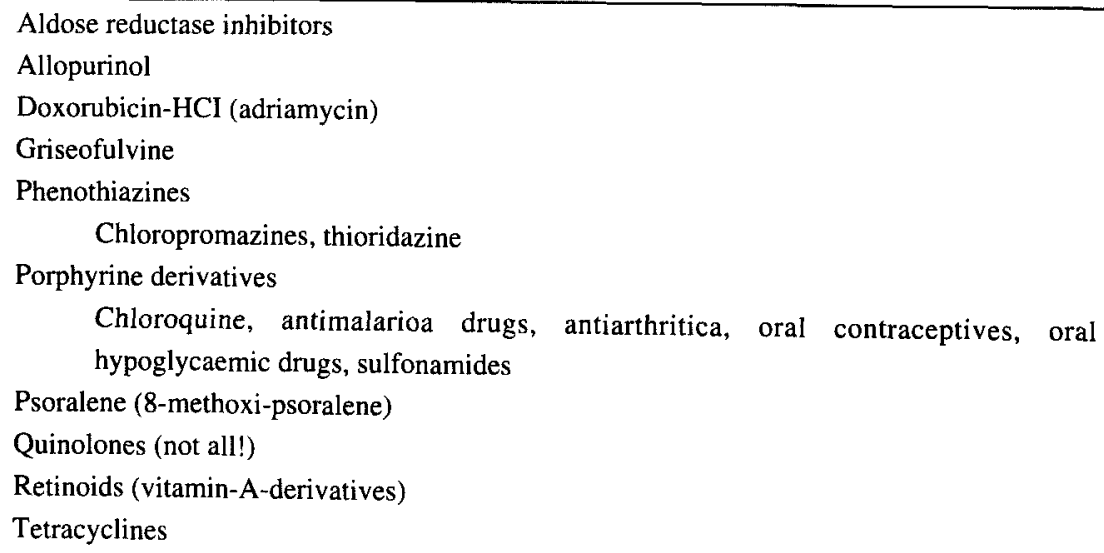


them for long-term treatment, increase the sensitivity of the skin and of the eye (photosensitizer effect) thus incuring a further often neglected risk potential (Table 3 ).

\section{CONCLUSIONS}

The only effective treatment of cataract is the surgical removal of the opaque lens (opacified lens proteins are irreversible damaged !) and if available the implantation of an artificial intraocular lens, thus protection against UV radiation is of predominant importance for the prevention of cataracts.

This can be provided by appropiate sunglasses being perfect UV filters ${ }^{32,33)}$ or by UV-absorbing contact lenses ${ }^{34)}$ but also in part by using appropiate shadowing devices (e.g. hats) The shape and size of sunglasses, even the form of the frames can provide additional protection against UV stray light (ground reflection) and from the side (Figures 9, 10).

Above all, avoiding unnecessary UV exposure is the best protection for the eyes (and the skin).

\section{IN SUMMARY}

There is no longer doubt about the damage by UV-radiation to the eye lens. We have to differentiate 2 mechanism:

1) direct cataractogenicity, mostly overdosed radiation, professional accidents. Typical opacity of the anterior and superficial lens layers as seen in experimental animal cataracts by UV radiation $=$ acute lens damage /important participation of the

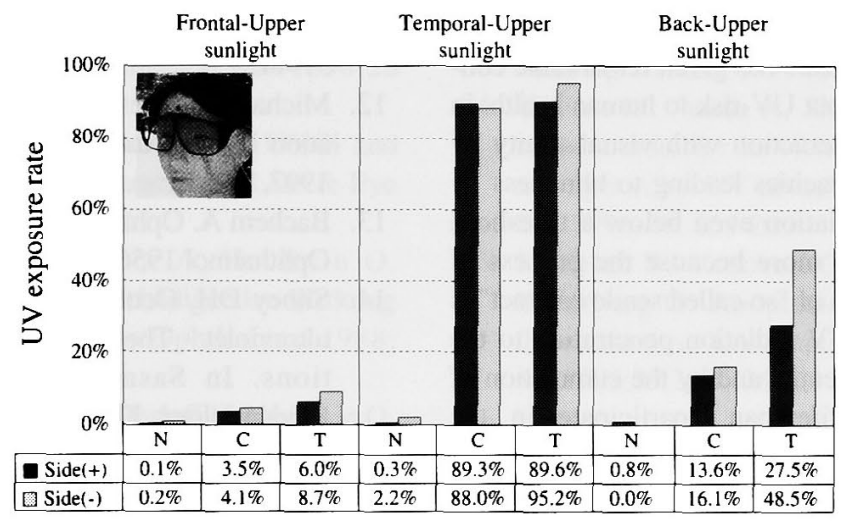

Sensor location on the palpebral fissure

Figure 9. UV exposure and sun-glasses with side protector (Sakamoto, personal communication).

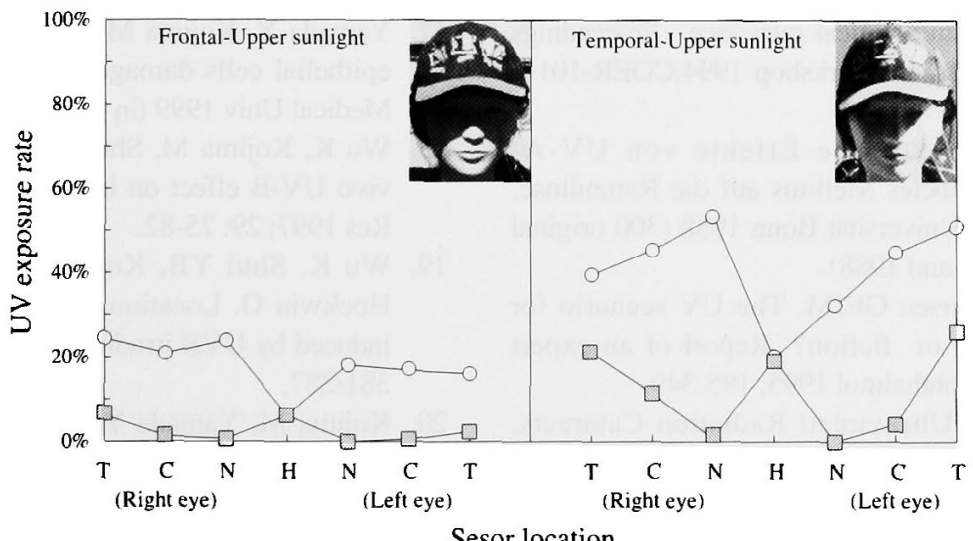

Sesor location

- - Cap $-\square-$ Cap + Eyeglasses( $54 \square 15-132)$

Figure 10. UV exposure with cap and with eye glasses (Sakamoto, personal communication). 
lens epithelial layer ${ }^{35}$.

2) syn- or cocataractogenic mechanism: promotion of processes, leading to cataracts of different types (important cataract classification!), The trigger probably is a

* disturbance of the carbohydrate metabolism,

* a decrease of the metabolic energy availability,

* a change of the redox potential with a decrease in the oxidative defense system,

* disturbances within the protein composition with possible acceleration to form posttranslational molecule modifications and also enzyme metazymes or inactivate enzyme systems and/or

to nuclear coloration due to UV-catalysed biochemical reactions with tryptophane $\rightarrow$ (photodegradation) $\rightarrow \mathrm{N}$ formylkynurenin, both are chronic lens damages/ participation of the epithelial layer as localisation of an important trigger very questionable.

Basic research of the past 5 years has given remarkable contributions to our knowledge about UV-risk to human health, in our case to the problem of interaction with visual acuity by promoting the onset of lens opacities leading to blindness by cataracts. Indeed, the UV radiation even below a threshold dose is dangerous and this so more because the process of human cataractogenesis in form of "so called senile cataract" is a multifactorial process, the UV radiation penetrating to the lens has a cocataractogenic potential and by the cumulation of the radiation effects over the life span it participates in the pathomechanism of cataracts. Thus prevention is of utmost importance, the adequate enlightenment of the population about the details by public health organisations should be activated.

\section{REFERENCES}

1. Hockwin O. UV-B induced eye injuries, especially of the lens. Basic research and clinical relevance. Proceedings of the TSUKUBA Ozone Workshop 1994,CGER-1014'94; 119-124.

2. Schmidt J.Cokataraktogene Effekte von UV-ABestrahlung und Diabetes Mellitus auf die Rattenlinse. Diss. Med. Fakultät Universität Bonn 1988 (300 original papers between 1909 and 1988).

3. van Rongen E, Vrensen GFJM. The UV scenario for senile cataract: Fact or fiction? Report of an expert workshop. Docum Ophthalmol 1995; 195-349.

4. Lerman S. Human Ultraviolett Radiation Cataracts. Ophthalmic Res 1980; 12:303-314.

5 Müller-Breitenkamp U, Hockwin O, Siekmann H, Dragomirescu V. Ultraviolett Radiation as Cataract Risk Factor - A Case Report. In: Sasaki K and Hockwin O. Eds. Cataract Epidemiology. Dev.Ophthalmol. Basel, Karger 1997, Vol.27:76-80.
6. Siekmann H, Hockwin O, Müller-Breitenkamp U. Grauer Star durch UV- Strahleneinwirkung. Begutachtung eines Berufskrankheiten-Falls und Bestimmung der Schädigungsdosis. Arbeitsmed. Sozialmed. Umweltmed. 1997; 32/10: 385-393.

7. Sasaki K. Cataract Epidemiology performed with Scheimpflug Documentation. Ophthalmic Res 1999; 31:75-85.

8. Harding, JJ. The untenability of the sunlight hypothesis of cataractogenesis. Docum Ophthalmol 1995; 88:345-349.

9. Sasaki, K. Epidemiology - Search for Risk Factors of Cataract Formation. Nova Acta Leopoldina NF 75, 1997) Nr. 299: 25-36.

10. Hockwin $O$. The causes and prevention of cataract blindness. Endeavour, New Series 1985; 9:132-138.

11. Hockwin O. Multifactorial Pathogenesis of "Senile Cataract". Nova Acta Leopoldina NF 75, 1997; Nr. 299: 37-44.

12. Michael R. Threshold dose estimation for ultraviolet radiation induced cataract. Stockholm: Karolinska Institutet; 1997, Thesis.

13. Bachem A. Ophthalmic ultraviolet action spectra. Amer $\mathbf{J}$ Ophthalmol 1956; 41:969-975.

14. Sliney DH. Ocular exposure to environmental light and ultraviolet - The impact of lid opening and sky conditions. In Sasaki K. Hockwin O. Eds. Cataract Epidemiology. Dev Ophthalmol Basel, Karger 1997; vol 27:63-75.

15. Sakamoto Y, Kojima M, Emori Y, Sasaki K. Ultraviolet Dosimetry utilizing a Mannequin Model. In Sasaki K, Hockwin O. Eds. Cataract Epidemiology. Dev Ophthalmol Basel, Karger 1997; vol 27: 50-55.

16. Sydenham MM, Collins MJ, Hirst LW. Measurement of ultraviolet radiation at the surface to the eye. Invest Ophthalmol Vis Sci 1997; 38:1485-1492.

17. Yamada Y, Kojima M. Repairing process of rabbit lens epithelial cells damaged by ultraviolet-B. J Kanazawa Medical Univ 1999 (in press).

18. Wu K, Kojima M, Shui YB, Sasaki K, Hockwin O. In vivo UV-B effect on lens protein solutions. Ophthalmic Res 1997; 29: 75-82.

19, Wu K, Shui YB, Kojima M, Murano H, Sasaki K, Hockwin $\mathrm{O}$. Location and severity of rat lens damage induced by UVB irradiation. Jpn J Ophthalmol 1997; 41: 381-387.

20. Kojima M, Yamada Y, Sasaki K. Foto-damage and the repair process of lens epithelial cells induced by a single exposure ultraviolet light. ARVO 1999.

21. Kojima M, Wu K, Murano H, Shui YB Sasaki K. Lens epithelium cells damage - Comparison of ultraviolet sensitivity between rats and guinea pigs. Atarashii Gganka (J.Eye) 1998; 15:259-262 (jap.). 
22. Hockwin O, Koch HR. Combination of noxious influences on the crystalling lens In: Bellows JG ed. Cataract and abnormalities of the lens. New York, Grune \& Stratton 1975: 243-254.

23. Hockwin O, Wegener A. Syn- and co-cataractogenesis. A system for testing lens toxicity. In: Hockwin O. ed. Drug-induced ocular side effects and ocular toxicology. Concepts Toxicol Karger Basel 1987:Vol.4:241-249.

24. Forker C, Wegener A, Graw J. Effects of UV-B radiation on a hereditary suture cataract in mice. Exper Eye Res 1997; 64: 405-411.

25. Malik A, Kojima M, Sasaki K. Morphological and biochemical changes in lenses of guinea pigs after vitamin $C$ deficient diet and UV-B radiation. Ophthalmic Res 1995; 27: 189-196.

26. Hatano T. Kojima M. UV-B-induced cataract model in Brown-Norway rat eyes combined with preadministration of buthionine sulfoximine. Ophthalmic Res 199628 (suppl 2);54-63.

27. Kojima M. Regional enzymatic analysis of UV-B and streptozotocin induced diabetic cataract lens. Lens \& Eye Tox Res 1990; 7:547-561.

28. Schmidt J, Schmitt C, Wegener A, Hockwin O. Experimenteller Beitrag zur linsenschädigenden Wirkung ultravioletter Strahlung. Fortschr Ophthalmol 1988; 85:689-694.

29. Schmidt J, Schmitt C,Wegener A, Ohrloff C, Hockwin O.
Syn- und kokataraktogene Wirkung ultravioletter Strahlung auf die Entwicklung einer diabetischen Katarakt. Spektrum Augenheilk 1988; 2: 1-6.

30. Wegener $A R$, Dwinger $M$, Heinitz $M$. Interactive Effects of $\mathrm{Zn} / \mathrm{Cr}$ and Vitamin E-deficiency on UV radiation damage to the lens in pigmented rats. Invest Ophthal Vis Sci 1996; 37(3): 3453.

31. Sasaki K, Sasaki H, Kojima M, Jonasson F, Shui YB, Cheng HM. Epidemiological studies on UV-related cataract in climatically different countries. International Workshop on the Health Effects of Ultraviolet Radiation, Tokyo 1999, Febr. 17-19.

32. Schmidt J, Schmitt C, Hockwin O. UV-absorption properties of commercially available eye glasses. Docum Ophthalmol. 1991; 77: 149.

33. Sakamoto Y, Kojima M, Sasaki K. Effectiveness of wearing eyeglasses for protection against ultraviolet exposure. Acta Ophthalmol 1999 (in press).

34. Kojima M, Sasaki K, Shui YB Sakamoto Y, Wu K. A rabbit model for in vivo evaluation of ultraviolet light absorption by UV-absorbing contact lenses J. Jpn. CL Soc 1996; 38: 205-209.

35. Michael R, Vrensen GFJM, van Marle J, Gan L, Söderberg G: Apoptosis in the rat lens after in vivo threshold dose UV irradiation. Invest Ophthalmol Vis Sci 1998;39:2681-2687. 